\title{
Rangelands Index for 2011
}

65th Annual SRM Meeting, February 2012, Spokane, Washington, 33(2):45

A

A Simple Graphical Approach to Quantitative Monitoring of Rangelands, 33(4):6

Adams, Laurie Davies, 33(4):84

AGWA: The Automated Geospatial Watershed Assessment

Tool to Inform Rangeland

Management, 33(4):41

An Introduction to the Special

Issue on Pollinators, 33(3):3

An Overview of Pollination in

Rangelands: Who, Why, and

How, 33(3):4

Anderson, David L., 33(1):2

Are Weather and Tradition

Reducing Our Ability to Conduct

Prescribed Burns?, 33(1):25

Art to Science: Tools for Greater

Objectivity in Resource

Monitoring, 33(4):27

B

Barnes, Matthew K., 33(2):31

Barrett, Hugh, 33(1):41

Bawtree, Alfred, 33(3):45

Beef and Beyond: Paying for

Ecosystem Services on Western

US Rangelands, 33(5):4

Belnap, Jayne, 33(4):6

Bestelmeyer, Brandon T., 33(1):13

Black, Scott Hoffman, 33(3):9

Blew, Roger, 33(3):63

Bobo, Matthew R., 33(4):14

Bonvissuto, Griselda L., 33(1):2

Booth, D. Terrance, 33(4):27

Box, Thad, 33(1):43, 33(2):49,

33(3):58, 33(4):73, 33(5):43

Breckenridge, Robert, 33(5):30

Brizuela, Miguel A., 33(1):2
Brown, Joel, 33(3):64

Browsing the Literature, 33(1):45, 33(2):53, 33(3):66, 33(4):81, 33(5):52

Buckhouse, John, 33(2):45

Burns, I. Shea, 33(4):41

Buzzing the Literature, 33(3):42

C

California's Rangeland Water

Quality Management Plan:

An Update, 33(1):20

Call, Christopher A., 33(2):2

Cane, James H., 33(3):27

Chaplin-Kramer, Rebecca, 33(3):33

Charnley, Susan, 33(5):20, 33(5):25

Chiossone, Guillermo, 33(1):2

Cibils, Andrés F., 33(1):2

Cid, M. Silvia, 33(1):2

Clark, Jason, 33(4):55

Colson, Karen, 33(4):48

Consistent Indicators and

Methods and a Scalable Sample

Design to Meet Assessment,

Inventory, and Monitoring

Information Needs Across

Scales, 33(4):14

Courtright, Ericha M., 33(4):21

Cows Eat Weeds: How to

Turn Your Cows Into Weed

Managers, 33(1):51

Cox, Samuel E., 33(4):27

Crane, Kelly, 33(4):71

Cross-Fencing on Private US

Rangelands: Financial Costs

and Producer Risks, 33(2):41

Derner, Justin D., 33(2):41

Duke, Clifford S., 33(5):30

Duniway, Michael C., 33(4):35

E

Editorial, 33(3):64

Edwards, Zach, 33(1):13
Energy Development and Wildlife

Conservation in Western North

America., 33(5):55

Engaging Ranchers in Market-

Based Approaches to Climate

Change Mitigation:

Opportunities, Challenges, and

Policy Implications, 33(5):20

ERRATUM, 33(2):55

Erratum, Chaplin-Kramer et al.

2011. Rangelands 33(3): 33-41, 33(5):42

F

Fankhauser, Terry, 33(5):13

Farley, Cary, 33(4):6

Fauske, Gerald M., 33(3):20

Feldman, Israel, 33(1):2

Fernández Grecco, Roberto C., 33(1):2

Finzel, Julie A., 33(2):10

Fire Management in the National Wildlife Refuge System: A Case Study of the Charles M. Russell National Wildlife Refuge,

Montana, 33(2):17

Food Digestibility by Microbes in Wild Ruminants: The Effect of Host Species and Dietary

Substrate, 33(1):31

Fox, Kristina, 33(3):20

Fox, William E., 33(5):30

Fuhlendorf, Samuel D., 33(2):17

Fur, Gold, and Settlement:

The Building Blocks of Range

Management in British

Columbia, 33(3):45

G

Ganguli, Amy C., 33(3):3, 33(3):4

George, Melvin, 33(1):20

Gilgert, Wendell, 33(3):14 
Goldstein, Joshua H., 33(5):13, 33(5):4

Goodrich, David C., 33(4):41

Gosnell, Hannah, 33(5):20, 33(5):25

Grazing Systems: More Thoughts and Observations, 33(1):35

Greetings From Charter Member

E. William Anderson, 33(2):46

Guertin, D. Phillip, 33(4):41

$\mathrm{H}$

Hanson, Craig, 33(5):13

Harmon, Jason P., 33(3):3, 33(3):4

Harper, John, 33(1):20

Harris, Marion O., 33(3):20

Hart, Charles, 33(3):64

Heilman, Philip, 33(4):41

Heintz, H. Theodore, 33(5):30

Hernandez, Mariano, 33(4):41

Herrick, Jeffrey E., 33(4):6, 33(4):14

Hidinger, Lori, 33(3):64, 33(5):2, 33(5):30

Highlights, Rangeland Ecology $\xi^{\circ}$ Management, 33(1):48, 33(2):56, 33(3):69, 33(4):78, 33(5):49

Howery, Larry, 33(1):51

Hughes, Lee E., 33(1):35

Hutchinson, Barbara, 33(4):55

Hyde, Gretchen, 33(4):71

I

ICARDA's Rangeland Ecology and Management Research Strategy for Nontropical Dry

Areas, 33(4):64

Idaho Rangeland Resource

Commission: Commitment to

Rangeland Education, 33(4):71

Image Interpreter Tool: An

ArcGIS Tool for Estimating

Vegetation Cover From

High-Resolution Imagery, 33(4):35

Implementing Ecologically Based Invasive Plant Management:
Lessons From a Century of Demonstration Projects in Park Valley, Utah, 33(2):2

J

Johnson, Kendall, L., 33(5):37

Johnson, Mari-Vaughn V., 33(2):10

Jolley, Leonard, 33(4):41

K

Karasov, William H., 33(1):31

Karl, Jason W., 33(4):3, 33(4):14, 33(4):48

Karl, Michael "Sherm", 33(4):14

Kepner, William G., 33(4):41

Kiniry, James R., 33(2):10

Knight, Kevin Bracy, 33(2):41

Knight, Richard L., 33(5):2,

33(5):4

Kremen, Claire, 33(3):33

Kreuter, Urs P., 33(5):30

Kunst, Carlos, 33(1):2

L

Lake Missoula and Its Floods, 33(5):37

Land Lines, 33(3):60, 33(4):75, 33(5):45

Larson-Praplan, Stephanie, 33(1):20

Laverty, Maura, 33(5):40

Lennox, Michael, 33(1):20

Letter to the Editor, 33(2):51, 33(3):63, 33(4):84

Lewis, David, 33(1):20

Listening to the Land, 33(1):43, 33(2):49, 33(3):58, 33(4):73, 33(5):43

López-Hoffman, Laura, 33(5):4

Louhaichi, Mounir, 33(4):64

Low-Input Grassfed Livestock

Production in the American

West: Case Studies of

Ecological, Economic, and

Social Resilience, 33(2):31
M

Maczko, Kristie, 33(5):30

Mann, Roy S., 33(2):47

McClaran, Mitchel P., 33(4):41

McCollum, Daniel W., 33(5):30

Meeting Wild Bees' Needs on

Western US Rangelands, 33(3):27

Miller, Scott N., 33(4):41

Mitchell, John E., 33(5):30

Moir, William H., 33(3):50

Monaco, Thomas A., 33(2):2

Morris, Lesley R., 33(2):2

Mosley, Jeff, 33(1):45, 33(2):53, 33(3):66, 33(4):81, 33(5):52

N

Nabhan, Gary P., 33(5):4

Naya, Daniel E., 33(1):31

Nearing, Mark A., 33(4):41

Oesterheld, Martín, 33(1):2

Oliva, Gabriel E., 33(1):2

On Renner, Russell, and "The

Trail Boss"-A Footnote for a Footnote, 33(2):47

P

Paige, Ginger B., 33(4):41

Paruelo, José M., 33(1):2

Peinetti, H. Raúl, 33(1):2

Perspectives on Rangeland Management Education and

Research in Argentina, 33(1):2

Pfander, Jeanne, 33(4):55

Pierson, Fred, 33(4):41

Presnall, Carrie K., 33(5):4

Profiting From the Sale of

Carbon Offsets: A Case Study

of the Trigg Ranch, 33(5):25

R

Ralphs, Michael, 33(2):2

Rangeland Assessment and Monitoring Methods Guide, 33(4):48

Rangeland Ecosystem Goods and Services: Values and Evaluation 
of Opportunities for Ranchers and Land Managers, 33(5):30

Rangeland Ecosystem Services, Risk Management, and the Ranch Bottom Line, 33(5):13

Rangeland Management for

Pollinators, 33(3):9

Rangelands and Ecosystem Services: Economic Wealth

From Land Health?, 33(5):2

Rangelands West/Global

Rangelands, eXtension

Rangelands, and the Range

Science Information System:

A Suite of New Web Resources, 33(4):55

Reid, Angela M., 33(2):17

Riginos, Corinna, 33(4):6

Robinson-Maness, Nicole, 33(5):13, 33(5):20, 33(5):25

Ross, Andrew A., 33(3):20

Rostker, Margaret, 33(5):42

Ruyle, George B., 33(5):4

Ruyle, George, 33(4):41

\section{S}

Salo, Cindy, 33(3):60, 33(4):75, 33(5):45

Sanchez, Homer, 33(2):10

Schrader, T. Scott, 33(4):35

Sheley, Roger L., 33(2):2

Shepherd, Matthew, 33(3):9

Skaggs, Rhonda, 33(1):13

Smith, Lamar, 33(2):51

Smith, Phil, 33(1):13

Solga, Michelle J., 33(3):4

Solga, Michelle, 33(3):42

Spaeth, Ken, 33(4):41
Spanel, Deborah, 33(2):10

Special Issue Acknowledgments, 33(3):2, 33(4):2

Spokane 2012 Winter Dance

Lessons from the Past-

Strategies for the Future 65th

Annual SRM Meeting, 33(1):41

Spurrier, Carol S., 33(4):14

SRM, 33(2):55

Stone, Jeffry J., 33(4):41

Sundaresan, Siva R., 33(4):6

Swartz, Heather, 33(4):48

$\mathrm{T}$

Tanaka, John A., 33(5):30

Tanaka, John, 33(4):55

Taylor, Jason J., 33(4):14

The Artist Behind the Winter

Dance Logo: Smoker Marchand, 33(5):40

The Carbon Ranch, 33(2):24

The Database for Inventory,

Monitoring, and Assessment

(DIMA), 33(4):21

The Hidden Benefits of Pollinator

Diversity for the Rangelands of

the Great Plains: Western

Prairie Fringed Orchids as a

Case Study, 33(3):20

The Rancher's ALMANAC, 33(2):10

The Value of Pollinators and

Pollinator Habitat to

Rangelands: Connections

Among Pollinators, Insects,

Plant Communities, Fish, and

Wildlife, 33(3):14
Thirty Years of Weather Change and Effects on a Grassland in the Peloncillo Mountains, New Mexico, 33(3):50

Thorpe, Jim, 33(5):2

Toevs, Gordon R., 33(4):14

Toombs, Ted, 33(5):13

Toombs, Theodore P., 33(2):41, 33(5):4

Travers, Steven, 33(3):20

Turning Information Into

Knowledge for Rangeland

Management, 33(4):3

Tuxen-Bettman, Karin, 33(3):33

V

Value of Wildland Habitat for Supplying Pollination Services to Californian Agriculture, 33(3):33

Van Zee, Justin W., 33(4):21

Vaughan, Mace, 33(3):9, 33(3):14

Vegetation Maps at the Passage of the Taylor Grazing Act (1934): A Baseline to Evaluate Rangeland Change After a Regime Shift

Villagra, E. Sebastián, 33(1):2

W

Wei, Haiyan, 33(4):41

Weir, John R., 33(1):25

Weltz, Mark, 33(2):10, 33(4):41

White, Courtney, 33(2):24

Williamson, Jeb, 33(1):13

Wright, John B., 33(1):13

Z

Zabek, Lisa, 33(3):45 